\title{
ANALISIS PENANGANAN PERMUKIMAN KUMUH DI KECAMATAN MEDAN DENAI
}

\author{
M. Rizky Akbar, Nina Novira \\ Jurusan Pendidikan Geografi Fakultas IImu Sosial Universitas Negeri Medan \\ Jl. Williem Iskandar Psr V Medan Estate Medan, 20211 Indonesia \\ Email: mraz.tan@gmail.com
}

\begin{abstract}
Slum has still been a problem in the City of Medan. However, the effort in dealing with it is suspected to be inadequate. Thus, study aims to find out the rate of slum in Denai District and slum handling pattern in Denai District. This research was conducted at the Denai District. The study was conducted in all villages identified slums in Denai District that is Tegal Sari Mandala II Village and Tegal Sari Mandala III Village. Data collection techniques in this study were observation and interview. The data analysis technique used is qualitative descriptive. The results showed that the rate of slum in Denai District in Tegal Sari Mandala II Village is mild slum and Tegal Sari Mandala III Village is mild slum. While slum handling pattern done in Denai District is restoration. Handling made in Tegal Sri Mandala II Village is improvement of drainage and culverts structures, concretes plates and waste facilities like waste cart. While handling made in Tegal Sri Mandala III Village is improvement of drainage structures, waste water management system and waste facilities. Generally, the handling effort has not succeeded in improving the slum status of the neighborhood.
\end{abstract}

Keywords: Rate of Slum, Handling Pattern, Slum

\begin{abstract}
Abstrak
Pemukiman kumuh masih menjadi masalah di Kota Medan. Namun, upaya penanganannya disinyalir masih kurang memadai. Karena itu penelitian ini bertujuan untuk mengetahui tingkat Kekumuhan di Kecamatan Medan Denai dan pola penanganan permukiman kumuh di Kecamatan Medan Denai. Penelitian ini dilaksanakan di Kecamatan Medan Denai. Lokasi penelitian ini adalah seluruh kelurahan yang teridentifikasi kumuh di Kecamatan Medan Denai yaitu 2 kelurahan yang terdiri dari Kelurahan Tegal Sari Mandala Il dan Tegal Sari Mandala III. Teknik pengumpulan data dalam penelitian ini adalah observasi dan wawancara. Teknik analisis data yang digunakan adalah deskriptif kualitatif. Hasil penelitian menunjukkan bahwa tingkat kekumuhan yang terdapat di Kecamatan Medan Denai adalah Kelurahan Tegal Sari Mandala II masuk dalam kategori kumuh ringan, Kelurahan Tegal Sari Mandala III masuk dalam kategori kumuh ringan. Sedangkan pola penanganan yang dilakukan di Kecamatan Medan Denai adalah pemugaran. Penanganan yang telah dilakukan di Kelurahan Tegal Sari Mandala II adalah perbaikan struktur drainase dan gorong-gorong, plat beton dan sarana persampahan bak sampah. Sedangkan penanganan yang telah dilakukan di Kelurahan Tegal Sari Mandala III adalah perbaikan struktur drainase, sistem pengelolaan air limbah dan sarana persampahan. Secara umum upaya yang telah dilakukan masih belum mampu meningkatkan status pemukiman tersebut menjadi tidak kumuh.
\end{abstract}

Kata Kunci: Tingkat Kekumuhan, Pola Penanganan, Permukiman Kumuh 


\section{PENDAHULUAN}

Masalah permukiman kumuh merupakan masalah tanpa akhir (the endless problems) yang setiap tahunnya termasuk dalam program pemerintah sesuai dengan UU No.1 Tahun 2011 Tentang Perumahan dan Kawasan Permukiman bahwa setiap orang berhak hidup sejahtera lahir dan batin, bertempat tinggal dan mendapatkan lingkungan hidup yang baik dan sehat, yang merupakan kebutuhan dasar manusia, dan yang mempunyai peran yang sangat strategis dalam pembentukan watak serta kepribadian bangsa sebagai salah satu upaya membangun manusia Indonesia seutuhnya, berjati diri mandiri dan produktif. Namun, masalah ini dari tahun ke tahun masih menjadi masalah yang tak terpecahkan (Hariyanto, 2017).

Kota Medan yang merupakan ibukota provinsi di Sumatera Utara telah berkembang menjadi pusat perekonomian daerah dan regional yang penting di Pulau Sumatera. Kota Medan sebagai kota terbesar ketiga di Indonesia juga teridentifikasi memiliki masalah dalam penataan permukiman penduduk yaitu banyaknya kawasan kumuh (slum area) yang berada di Kota Medan. Adanya permukiman kumuh di Kota Medan memiliki dampak yang besar terhadap kondisi perkembangannya, dapat dilihat dari kemunduran kualitas, baik untuk lingkungan ekonomi, sosial dan budaya (Lubis, 2016).

Kecamatan Medan Denai telah ditetapkan memiliki 2 kelurahan dari 6 kelurahan yang teridentifikasi sebagai daerah kumuh yaitu Kelurahan Tegal Sari Mandala II dan Kelurahan Tegal Sari Mandala III, berdasarkan yang tertera di dalam Surat Keputusan Walikota Medan No.640/580.K/XI/2018 Tentang Penetapan Lokasi Lingkungan Perumahan dan Permukiman Kumuh di Kota Medan. Studi pendahuluan yang telah dilakukan menggambarkan masih banyaknya permasalahan yang ditemukan di kelurahan yang teridentifikasi kumuh. Beberapa diantaranya adalah kondisi jalan lingkungan yang masih kurang baik, pengelolaan persampahan yang masih belum rampung ditangani, dan sebagainya.
Menurut UU No. 1 Tahun 2011 Pasal 1 Ayat 13 tentang Perumahan dan Kawasan Permukiman, pengertian permukiman kumuh adalah permukiman yang tidak layak huni karena ketidakteraturan bangunan, tingkat kepadatan bangunan yang tinggi, dan kualitas bangunan serta sarana dan prasarana yang tidak memenuhi syarat. Ciri-ciri permukiman kumuh adalah letak dan bentuk perumahan yang tidak teratur, sarana dan infrastruktur kota sangat sedikit bahkan mungkin tidak ada sama sekali, tingkat pendidikan rendah, pendapatan rumah tangga dan pendapatan penduduk rendah serta kebanyakan bekerja disektor informal.

Menurut Amiany (2017), secara umum lingkungan kumuh dapat dibedakan menjadi dua yaitu daerah "slum" merupakan lingkungan hunian yang legal tetapi kondisinya tidak layak huni atau tidak memenuhi persyaratan sebagai tempat permukiman dan daerah. Hunian slums ditandai dengan mutu bangunan yang rendah, tidak teratur, tidak adanya/terbatasnya dan buruknya sarana fasilitas umum, sedangkan "squatter" yaitu ruang-ruang terbuka yang ditempati oleh permukimanpermukiman liar. Hunian squatter tidak selalu mempunyai ciri-ciri kumuh, tetapi lebih mengacu pada legalitas lahan yang ditempati dimana permukiman berada di atas lahan milik pihak lain. Pada umumnya lingkungan permukiman liar berada di atas tanah negara, tanah perorangan, badan hukum dan tanah yayasan yang belum dibangun pemiliknya.

Tingkat kekumuhan dalam suatu lingkungan permukiman dapat diukur dengan melihat pada variabel-variabel yang signifikan terhadap terjadinya kondisi kumuh. Kriteria perumahan kumuh dan permukiman kumuh merupakan kriteria yang digunakan untuk menentukan kondisi kekumuhan pada perumahan kumuh dan permukiman kumuh. Kriteria perumahan kumuh dan permukiman kumuh meliputi kriteria kekumuhan ditinjau dari Peraturan Menteri Pekerjaan Umum dan Perumahan Rakyat Republik Indonesia No. 14 Tahun 2018 Tentang Pencegahan 
dan Peningkatan Kualitas Terhadap Perumahan Kumuh dan Permukiman Kumuh.

Identifikasi permasalahan kekumuhan merupakan tahap identifikasi untuk menentukan permasalahan kekumuhan pada objek kajian yang difokuskan pada aspek kualitas fisik bangunan dan infrastruktur keciptakaryaan pada suatu lokasi. Identifikasi permasalahan kekumuhan dilakukan berdasarkan pertimbangan pengertian perumahan kumuh dan permukiman kumuh dengan persyaratan teknis yang berlaku serta standar pelayanan minimal yang diprasyaratkan secara nasional. Upaya untuk menentukan tingkat kekumuhan pada suatu permukiman dengan menemukenali dari setiap lokasi disebut identifikasi kondisi kekumuhan yang meliputi berbagai aspek seperti kondisi bangunan gedung, kondisi jalan lingkungan, kondisi penyediaan air minum, kondisi drainase lingkungan, kondisi pengelolaan air limbah, kondisi pengelolaan persampahan dan proteksi kebakaran. Identifikasi kondisi kekumuhan dilakukan berdasarkan beberapa aspek dan kriteria seperti yang telah dirumuskan pada Permen PUPR RI Nomor 14 Tahun 2018 Tentang Pencegahan dan Peningkatan Kualitas Perumahan Kumuh dan Permukiman Kumuh.

Penilaian lokasi pada identifikasi kondisi kekumuhan berdasarkan parameter yang telah ditentukan oleh Permen PUPR RI Nomor 14 Tahun 2018 Tentang Pencegahan dan Peningkatan Kualitas Perumahan dan Permukiman Kumuh dimana:

- Tingkat permukiman kumuh berat merupakan tingkatan dimana indikator permukiman kumuh terpenuhi pada rentan 76 $-100 \%$

- Tingkat permukiman kumuh sedang merupakan tingkatan dimana indikator permukiman kumuh terpenuhi pada rentan 51 $-75 \%$

- Tingkat permukiman kumuh ringan merupakan tingkatan dimana indikator permukiman kumuh terpenuhi pada rentan 25 $-50 \%$

Berdasarkan Permen PUPR RI Nomor 14 Tahun 2018 Tentang Pencegahan dan Peningkatan Kualitas Perumahan dan Permukiman Kumuh maka telah ditentukan tingkat kekumuhan permukiman kumuh di suatu wilayah melalui 3 tingkat skor, yaitu $60-80$ merupakan tingkat kumuh berat, 38 - 59 merupakan tingkat kumuh sedang dan 16 - 37 merupakan tingkat kumuh ringan.

Menurut (Jamaluddin, 2015) penyebab utama tumbuhnya permukiman kumuh adalah sebagai berikut:

1. Urbanisasi dan migrasi yang tinggi, terutama bagi kelompok masyarakat yang berpenghasilan rendah.

2. Sulit mencari pekerjaan.

3. Sulitnya mencicil atau menyewa rumah.

4. Kurang tegasnya pelaksanaan perundang-undangan.

5. Perbaikan lingkungan yang hanya dinikmati oleh para pemilik rumah serta disiplin warga yang rendah.

Pesatnya pertumbuhan penduduk yang diikuti dengan semakin meningkatnya kebutuhan akan ruang bermukim menyebabkan pembangunan yang tidak disertai dengan pengaturan dan pengendalian yang baik menjadikan suatu lingkungan itu kumuh. Selain itu penyebab lain yang menjadi faktor terjadinya permukiman kumuh (Sembiring, 2017) adalah:

1. Karakter bangunan, yaitu umur bangunan yang sudah terlalu tua, tidak terorganisasi, ventilasi, pencahayaan, dan sanitasi tidak memenuhi syarat

2. Karakter lingkungan, yaitu tidak ada ruang terbuka hijau (open space) dan tidak tersedianya fasilitas rekreasi keluarga, kepadatan penduduk yang tinggi dan prasarana serta sarana yang tidak terencana dengan baik.

Menurut Kamus Besar Bahasa Indonesia kata Penanganan adalah proses, cara perbuatan, menangani, penggarapan. Dalam upaya peningkatan 
kualitas terhadap perumahan dan permukiman kumuh maka diterapkan pola-pola penanganan permukiman kumuh yang dilihat dari hasil penilaian aspek kondisi kekumuhan dan aspek legalitas tanah. Pola-pola penanganan permukiman kumuh terdiri dari 3 tahap menurut Peraturan Menteri Pekerjaan Umum dan Perumahan Rakyat Republik Indonesia No. 14 Tahun 2018 tentang Pencegahan dan Peningkatan Kualitas Perumahan dan Permukiman Kumuh, adapun beberapa tahap dalam pola penanganan permukiman kumuh, meliputi: pemugaran, peremajaan dan pemukiman kembali.

\section{METODOLOGI PENELITIAN}

Penelitian ini dilakukan di daerah permukiman kumuh di Kecamatan Medan Denai. Adapun alasan penulis melakukan penelitian di lokasi ini didasarkan pada pertimbangan sebagai berikut:

1. Kecamatan Medan Denai merupakan salah satu kecamatan yang memiliki kepadatan penduduk yang tinggi.

2. Untuk menganalisis penanganan permukiman kumuh yang telah dikerjakan oleh pemerintah dan masyarakat.

Penelitian ini dilakukan di 2 kelurahan di Kecamatan Medan Denai yang teridentifikasi kumuh menurut Surat Keputusan Walikota Medan No.640/580.K/XI/2018 tentang
Penetapan Lokasi Lingkungan Perumahan dan Permukiman Kumuh di Kota Medan, yaitu Kelurahan Tegal Sari Mandala II dan Tegal Sari Mandala III. Sampel yang digunakan dalam penelitian ini adalah dengan cara purposive sampling, dimana sampel adalah lingkungan yang tergolong kumuh yang terdapat di Kelurahan Tegal Sari Mandala II berjumlah 5 lingkungan yaitu lingkungan IV, V, VI, VII dan VIII. Sedangkan di Kelurahan Tegal Sari Mandala III berjumlah 4 lingkungan yaitu lingkungan IV, V, VII dan VIII. Total lingkungan yang tergolong kumuh di kedua kelurahan ini berjumlah 9 lingkungan.

Teknik pengumpulan data dalam penelitian ini adalah observasi dan wawancara. Pengamatan langsung bertujuan untuk melengkapi data-data yang diperlukan dan berkaitan dengan penelitian ini, seperti aspek kondisi bangunan gedung, kondisi jalan lingkungan, kondisi drainase lingkungan, kondisi pengelolaan persampahan dan kondisi proteksi kebakaran. Sedangkan wawancara digunakan untuk memperoleh informasi dengan membuat daftar pertanyaan tertulis yang disiapkan sebelumnya untuk mendapatkan jawaban dari informan mengenai penyediaan air minum, pengelolaan air limbah serta penanganan yang telah dilakukan pemerintah terhadap permukiman kumuh di daerah tersebut. Teknik Analisis dalam penelitian ini menggunakan deskriptif kualitatif.

Tabel 1. Tingkat Kekumuhan

\begin{tabular}{cl}
\hline Nilai & Kekumuhan \\
\hline $60-80$ & Kumuh Berat \\
\hline $38-59$ & Kumuh Sedang \\
\hline $16-37$ & Kumuh Ringan \\
\hline
\end{tabular}

Sumber: Data Primer Olahan, 2019 
Tabel 2. Pola Penanganan

\begin{tabular}{ccc}
\hline \multirow{2}{*}{$\begin{array}{c}\text { Tingkat } \\
\text { Kekumuhan }\end{array}$} & \multicolumn{2}{c}{ Pola Penanganan } \\
\cline { 2 - 3 } & Legal & llegal \\
\hline Kumuh & Peremajaan & $\begin{array}{c}\text { Permukiman } \\
\text { Kembali }\end{array}$ \\
Kumuh & Peremajaan & $\begin{array}{c}\text { Permukiman } \\
\text { Kembali }\end{array}$ \\
Sedang & & $\begin{array}{c}\text { Permukiman } \\
\text { Kumuh }\end{array}$ \\
Ringan & Pemugaran & Kembali \\
\hline \multicolumn{3}{c}{ Sumber: Data Olahan, 2019 }
\end{tabular}

HASIL PENELITIAN DAN PEMBAHASAN

\section{A. Hasil Penelitian}

\section{Tingkat Kekumuhan}

Tingkat kekumuhan di Kecamatan Medan Denai dapat dilihat dari 7 aspek yang ditetapkan oleh Permen PUPR RI No. 14 Tahun 2018 pada 9 lingkungan yang terdapat di Kecamatan Medan Denai. Berdasarkan penelitian yang telah dilakukan bahwa terdapat tingkat kekumuhan yang berbeda di setiap lingkungan yang termasuk kawasan kumuh yang ditinjau dari 7 aspek dan 16 kriteria yang telah ditetapkan sebagai berikut:

1. Kondisi Bangunan Gedung

Kondisi bangunan gedung termasuk aspek dalam penentuan kawasan kumuh yang dapat dilihat dari 3 kriteria berupa:
a. ketidakteraturan bangunan
b. tingkat kepadatan bangunan
c. kualitas bangunan

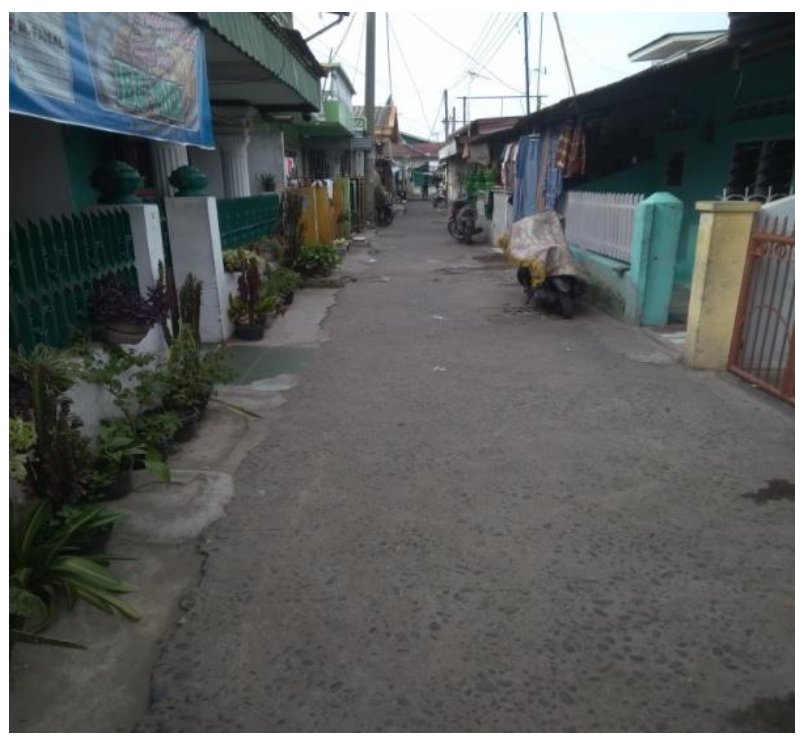

Gambar 1. Kondisi Bangunan Gedung

2. Kondisi Jalan Lingkungan

Jalan lingkungan merupakan jalan yang berada di lingkungan perumahan, jalan lingkungan terbagi atas dua yaitu jalan lingkungan primer yang menghubungkan antara lingkungan yang satu dengan lingkungan yang lain.
Sementara jalan lingkungan sekunder menghubungkan jalan lingkungan dengan jalan perkotaan. Kondisi jalan lingkungan dapat dilihat dari:

a. cakupan pelayanan jalan lingkungan

b. kualitas permukaan jalan lingkungan 


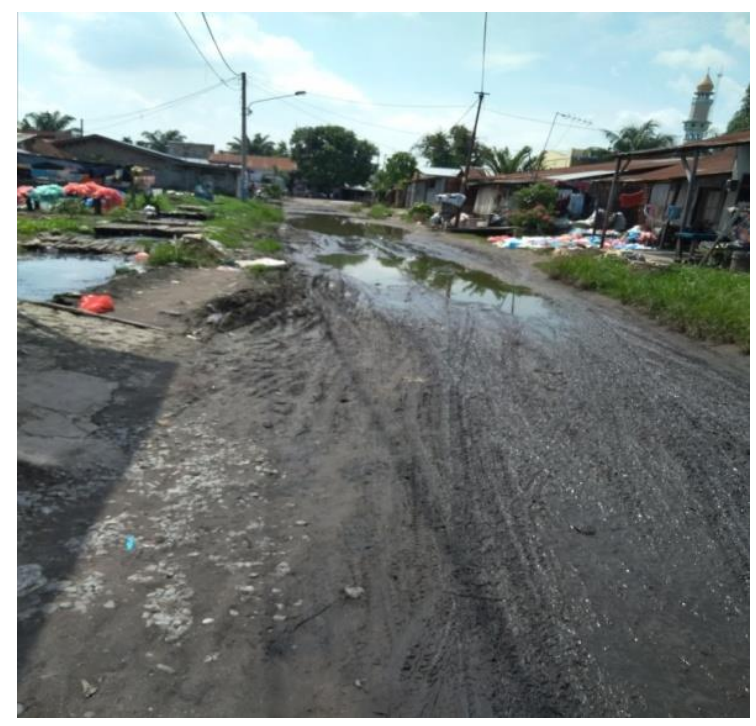

Gambar 2. Kondisi Jalan Lingkungan

3. Kondisi Penyediaan Air Minum

Penyediaan air minum harus dapat memenuhi setiap segi kehidupan masyarakat dan tersedia dalam jumlah yang cukup baik untuk disalurkan secara terus menerus. Penyediaan air minum menurut Peraturan Menteri PUPR RI No. 14 Tahun 2018 Tentang Pencegahan dan
Peningkatan Kualitas Terhadap Perumahan Kumuh dan Permukiman Kumuh dilihat dari:

a. ketidaktersediaan akses aman air minum

b. tidak terpenuhinya kebutuhan air minum setiap individu sesuai dengan standar yang berlaku.

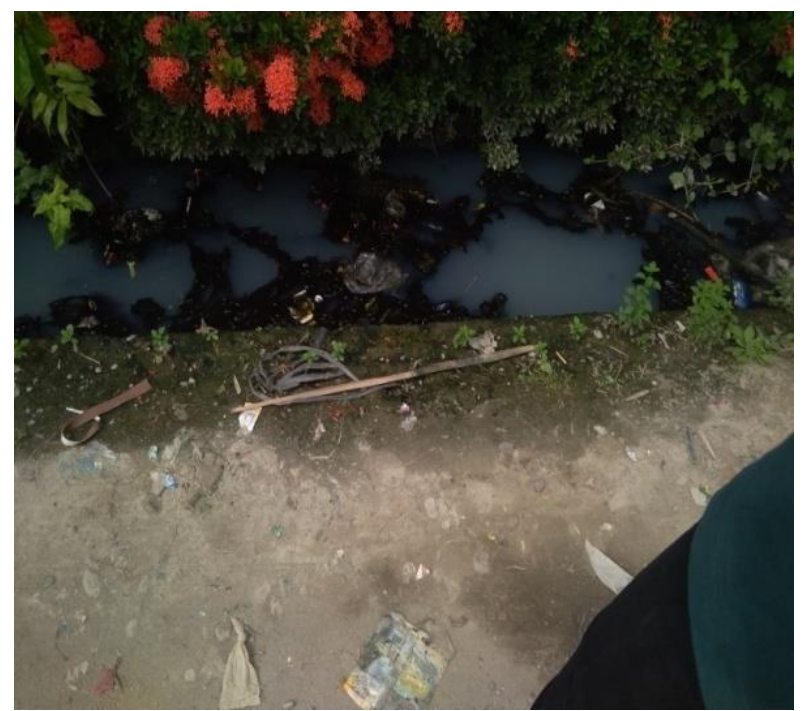

Gambar 3. Kondisi Drainase Lingkungan

4. Kondisi Drainase Lingkungan

Dalam kondisi drainase lingkungan dapat

dilihat dari 3 kriteria berupa:

a. ketidaktersediaan drainase b. ketidakmampuan mengalirkan limpasan

c. kualitas konstruksi drainase 


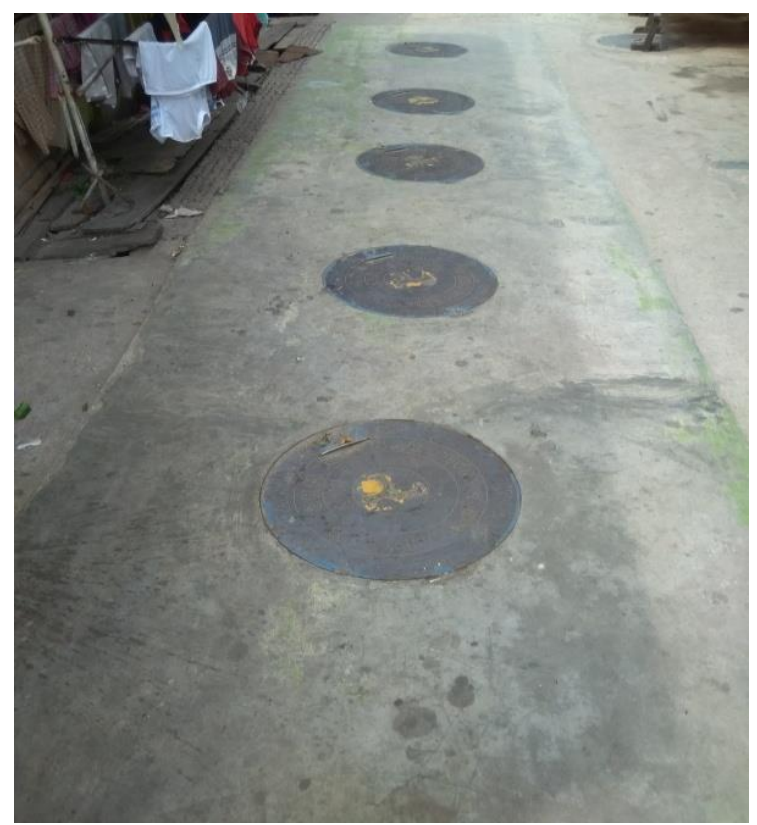

Gambar 4. Kondisi Pengelolaan Limbah

5. Kondisi Pengelolaan Air Limbah

Limbah merupakan semua buangan yang dihasilkan oleh aktivitas manusia dan hewan yang berbentuk padat, cair dan gas yang dibuang karena tidak diinginkan lagi. Air limbah yang dimaksudkan adalah limbah domestik yaitu limbah yang dihasilkan dari kegiatan rutin manusia dalam bentuk cair dari kegiatan mencuci pakaian dan makanan, mandi, kakus, dll. Beberapa indikator untuk melihat air limbah di Kecamatan Medan Denai yaitu:

a. sistem pengelolaan air limbah yang tidak sesuai standar teknis

b. sarana pengelolaan air limbah tidak sesuai dengan persyaratan teknis

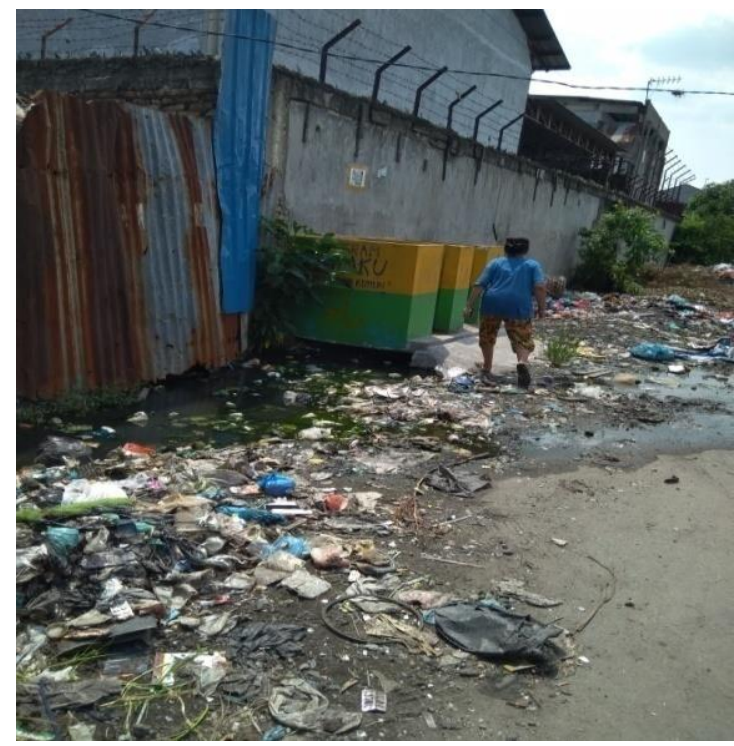

Gambar 5. Kondisi Persampahan

6. Kondisi Pengelolaan Persampahan Pengelolaan persampahan merupakan kegiatan yang sistematis dan berkesinambungan untuk mengurangi dan menangani persampahan di suatu tempat. Beberapa indikator dalam pengelolaan persampahan dengan melihat: 
a. sistem pengelolaan persampahan yang tidak sesuai standar teknis

b. tidak terpeliharanya sarana dan prasarana pengelolaan persampahan.

7. Kondisi Proteksi Kebakaran
Beberapa kriteria untuk melihat kondisi proteksi kebakaran adalah:

a. Kondisi ketersediaan prasarana proteksi kebakaran

b. Kondisi ketersediaan sarana proteksi kebakaran

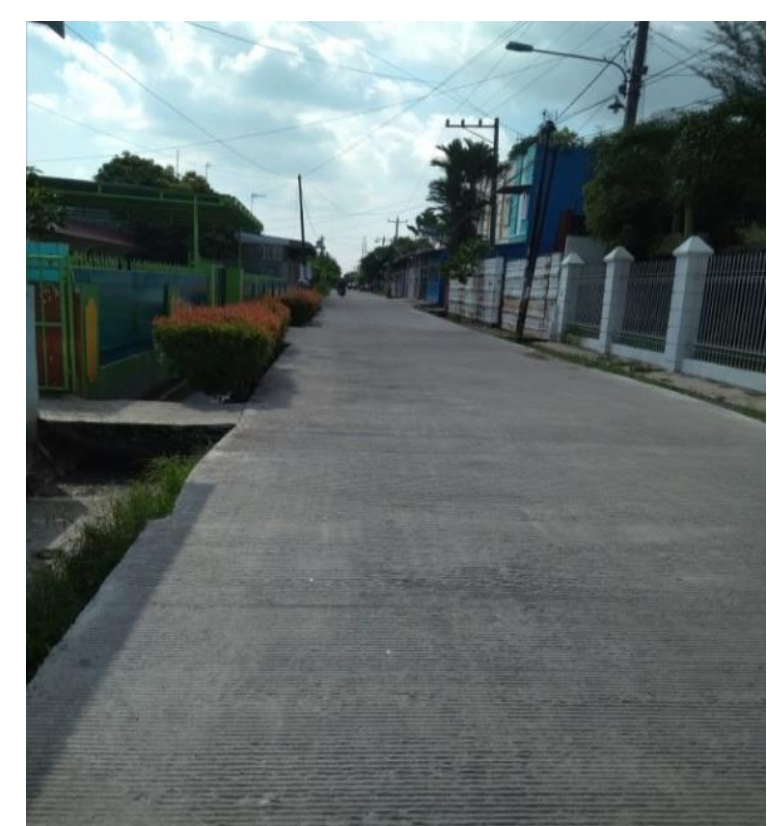

Gambar 6. Prasarana Proteksi Kebakaran

\begin{tabular}{cccc}
\multicolumn{4}{c}{ Tabel 3. Tingkat Kekumuhan di Kecamatan Medan Denai } \\
\hline Kelurahan & Lingkungan & Skor & Kekumuhan \\
\hline TSM II & IV & 30 & Ringan \\
TSM II & V & 34 & Ringan \\
TSM II & VI & 32 & Ringan \\
TSM II & VII & 34 & Ringan \\
TSM II & VIII & 30 & Ringan \\
TSM III & IV & 36 & Ringan \\
TSM III & V & 30 & Ringan \\
TSM III & VII & 30 & Ringan \\
TSM III & VIII & 36 & Ringan \\
\hline
\end{tabular}

Sumber: Data Primer Olahan, 2019

Berdasarkan 16 kriteria dalam 7 aspek tersebut maka dapat diketahui tingkat kekumuhan tiap lingkungan seperti pada tabel 3. Seluruh lingkungan terkategori dalam kelas kekumuhan ringan dengan rentang skor 30 s.d 36 . 


\section{Pola Penanganan}

Program dalam penanganan permukiman kumuh di Kecamatan Medan Denai melalui program KOTAKU (Kota Tanpa Kumuh) (Dirjen Cipta Karya, 2016). Program KOTAKU (Kota Tanpa Kumuh) adalah program yang dilaksanakan secara nasional yang menjadi basis penanganan permukiman kumuh yang mengintegrasikan berbagai sumber daya dan sumber pendanaan termasuk dari pemerintah pusat dan pemangku kepentingan lainnya. KOTAKU bermaksud untuk membangun sistem yang terpadu untuk penanganan permukiman kumuh, dimana pemerintah memimpin dan berkolaborasi dengan para pemangku kepentingan dalam perencanaan maupun implementasinya, serta mengedepankan partisipasi masyarakat dalam mewujudkan permukiman layak huni melalui revitalisasi peran Badan Keswadayaan Masyarakat (BKM).

KOTAKU diharapkan dapat mendukung penanganan permukiman kumuh melalui pengembangan kapasitas pemerintah dan masyarakat, penguatan kelembagaan, perencanaan, perbaikan infrastruktur dan pelayanan dasar di tingkat kota dan masyarakat. Serta pendampingan teknis untuk mendukung tercapainya sasaran Rancangan Pembangunan Jangka Menengah Nasional (RPJMN) tahun 2015 - 2019 yaitu dengan pencapaian tujuan program pengentasan permukiman kumuh perkotaan menjadi 0 persen.

Selain dengan Program KOTAKU (Kota Tanpa Kumuh), program dalam penanganan permukiman kumuh di Kecamatan Medan Denai juga melalui Program Sanimas IDB (Dirjen Cipta Karya, 2018). Sanimas IDB bermaksud untuk meningkatkan kualitas Sanitasi dan Kebersihan Lingkungan masyarakat, serta untuk melindungi kualitas air tanah dari pencemaran bakteri dan mengurangi pencemaran air. Sanimas IDB bertujuan untuk menyediakan layanan sanitasi dasar yang akan meningkatkan kesehatan dan mata pencaharian masyarakat serta untuk meningkatkan kesadaran masyarakat tentang Sanitasi dan Kebersihan Air. Selain diharapkan dapat membantu mengatasi masalah-masalah kesehatan yang disebabkan oleh kebiasaan buang air besar sembarangan dan sanitasi yang buruk dengan menyediakan infrastruktur sanitasi berbasis masyarakat. Tujuan khusus secara keseluruhan dari program ini adalah meningkatkan fasilitas sanitasi yang lebih baik. Pembuatan instalasi pengolahan air limbah yang fungsional tetapi mudah digunakan. Meningkatkan pembuangan air limbah dan kotoran serta mengurangi kemungkinan kontaminasi terhadap manusia dan lingkungan, dan melatih masyarakat setempat untuk merawat fasilitas-fasilitas tersebut. Prinsip dasar Program Sanimas IDB yaitu: Tanggap Kebutuhan, Seleksi, Teknologi, Partisipasi Masyarakat, Kesetaraan Gender, Berkelanjutan, Multi Pendanaan dan Akuntabel.

\section{B. Pembahasan}

1. Kondisi Bangunan Gedung

Berdasarkan hasil penelitian yang telah dilakukan di lapangan keteraturan bangunan, kepadatan bangunan dan kualitas bangunan masing-masing berada pada kriteria 25\%-50\%. Artinya, lebih dari setengah permukiman di lingkungan yang tergolong kumuh memiliki keteraturan bangunan yang baik, kepadatan bangunan yang tidak terlalu padat serta kualitas bangunan yang layak huni. Pola penanganan yang dilakukan untuk bangunan yang tergolong kumuh adalah rehabilitasi fungsi dan massa bangunan sesuai kondisi saat awal dibangun.

\section{Kondisi Jalan Lingkungan}

Hasil yang ditemukan di lapangan menunjukkan bahwa 8 dari 9 lingkungan yang tergolong kumuh telah terlayani oleh cakupan pelayanan jalan lingkungan. Sedangkan untuk kualitas jalan lingkungan masih tergolong buruk. Fakta di lapangan dapat dilihat beberapa jalan lingkungan dalam kondisi berlubang ataupun belum teraspal. Ataupun sebagian jalan lingkungan ditemukan dalam kondisi permukaan jalan yang tidak rata dan juga tergenang air. Diperlukan rehabilitasi jalan untuk mengembalikan kondisi kemantapan jalan saat awal dibangun seperti perbaikan struktur jalan. Sehingga seluruh 
jalan lingkungan terlayani dan kualitas permukaan jalan lingkungan dalam kondisi baik.

3. Kondisi Penyediaan Air Minum

Kondisi penyediaan air minum di Kecamatan Medan Denai sudah tersedia dan aman. Akses aman air minum didapatkan masyarakat dari Perusahaan Air Minum (PAM). Namun, sebagian besar masyarakat juga memperoleh air untuk minum dari Air Minum Isi Ulang dikarenakan ada juga masyarakat yang memperoleh air untuk keperluan seharihari dari sumur galian

4. Kondisi Drainase Lingkungan

Kondisi ketersediaan drainase lingkungan di Kecamatan Medan Denai tersedia dengan baik di setiap lingkungan yang tergolong kumuh. Sedangkan kondisi dimana jaringan drainase lingkungan tidak mampu mengalirkan limpasan air terdapat di 6 lingkungan. Hal ini terjadi dikarenakan kondisi drainase yang telah penuh sehingga tidak mampu menerima debit air. Diperlukan pengerukan drainase sehingga apabila terjadi hujan dengan intensitas yang tinggi tidak menyebabkan genangan air hingga banjir karena drainase telah dibersihkan dari endapan material dan mampu mengalirkan limpasan air hujan tersebut. Sementara itu untuk kualitas konstruksi drainase dapat dikatakan buruk jika drainase berupa galian tanah tanpa material pelapis. Tidak terpeliharanya drainase lingkungan juga dapat mengakibatkan saluran drainase tersumbat. Kualitas konstruksi drainase di Kecamatan Medan Denai masih tergolong buruk. Terdapat 6 dari 9 lingkungan kumuh dengan kualitas konstruksi drainase dalam kondisi kurang baik. Diperlukan rehabilitasi sarana dan prasarana drainase untuk mengembalikan kondisi sesuai dengan persyaratan teknis saat awal dibangun seperti perbaikan struktur drainase.

5. Kondisi Pengelolaan Air Limbah Sistem pengelolaan air limbah di Kecamatan Medan Denai masih dikatakan buruk. Pengelolaan air limbah pada lokasi permukiman tidak memiliki sistem yang memadai. Pola penanganan yang telah dilakukan oleh pemerintah adalah sudah terdapatnya pembangunan IPAL Komunal di beberapa lingkungan kumuh. Diharapkan dengan adanya pembangunan IPAL Komunal mampu membantu mengatasi masalah-masalah kesehatan dan sanitasi yang buruk dengan menyediakan infrastruktur sanitasi berbasis masyarakat. Prasarana dan sarana pengelolaan air limbah di Kecamatan Medan Denai telah memenuhi persyaratan teknis dimana kloset telah terhubung dengan tangki septik baik secara individu maupun terpusat.
6. Kondisi
Pengelolaan Persampahan

Sistem pengelolaan Persampahan di Kecamatan Medan Denai masih belum berjalan dengan baik. Hal ini disebabkan sarana pengangkut sampah seperti tempat sampah dengan pemilahan sampah skala lingkungan tidak berfungsi dengan semestinya. Kemudian jumlah gerobak sampah yang terbatas tidak mampu menampung sampah skala lingkungan. Sangat disayangkan prasarana dan sarana persampahan yang ada tidak berfungsi secara maksimal. Sistem pengelolaan persampahan di Kecamatan Medan Denai masih kurang baik. Banyak masyarakat yang membuang sampah sembarangan dan membuang sampah di lahan kosong, sehingga membuat lahan kosong tersebut menjadi tempat pembuangan sampah. Sebagian besar masyarakat juga ada yang membakar sampah di halaman rumahnya dikarenakan jarak lokasi tempat pembuangan sampah dengan rumah yang cukup jauh.

\section{Kondisi Proteksi Kebakaran}

Kecamatan Medan Denai tidak memiliki prasarana dan sarana proteksi kebakaran yang lengkap. Tidak ada satu pun lingkungan kumuh yang mempunyai alat pemadam api ringan (APAR), mobil tangga ataupun kendaraan pemadam kebakaran. Hanya jalan lingkungan yang dapat dilalui mobil pemadam kebakaran dan pasokan air yang berasal dari rumahrumah masyarakat dan Sungai Sulang Saling yang dapat dimanfaatkan sebagai prasarana proteksi kebakaran. Apabila terjadi kebakaran maka harus memanggil Dinas Pemadam Kebakaran terdekat yang berada di UPT Wilayah II Kec. Medan Amplas.

\section{KESIMPULAN}


Berdasarkan hasil penelitian diperoleh beberapa kesimpulan sebagai berikut:

1. Tingkat kekumuhan yang terdapat di Kelurahan Tegal Sari Mandala II dan Kelurahan Tegal Sari Mandala III masuk kedalam kategori Kumuh Ringan.

2. Sesuai dengan Permen PUPR RI No. 14 Tahun 2018 Tentang Pencegahan dan Peningkatan Kualitas Perumahan Kumuh dan Permukiman Kumuh, maka pola penanganan yang dilakukan di Kecamatan Medan Denai adalah Pemugaran.

3. Pola penanganan di Kelurahan Tegal Sari Mandala II yang perlu dilakukan adalah perbaikan struktur jalan, pengerukan drainase, TPS serta prasarana dan sarana proteksi kebakaran. Penanganan yang telah dilakukan adalah perbaikan drainase / gorong-gorong dan sarana persampahan bak sampah. Pola penanganan di Kelurahan Tegal Sari Mandala III yang perlu dilakukan adalah perbaikan struktur jalan, pengerukan drainase, proteksi kebakaran. Penanganan yang telah dilakukan adalah perbaikan drainase, sistem pengelolaan air limbah dan sarana persampahan bak sampah.

Berdasarkan hasil penelitian ini, dapat disarankan beberapa hal sebagai berikut

1. Perlu dilakukan sosialisasi dan aksi bersama dengan masyarakat tentang pentingnya kesadaran dalam menjaga kualitas lingkungan permukiman dan kesehatan lingkungan permukiman.

2. Perlunya menumbuhkan kesadaran untuk menjaga pola penanganan yang telah dilaksanakan dengan baik secara bersama-sama.

Bagi pemerintah, diharapkan program-program yang belum terealisasi agar secepatnya dapat dilaksanakan demi terwujudnya program-program yang telah direncanakan dan tentunya terealisasinya program tersebut dapat meningkatkan kualitas permukiman di daerah tersebut.

\section{DAFTAR PUSTAKA}

Amiany. 2017. Penanganan Fisik Permukiman Kawasan Kumuh di Kota Kapuas. Jurnal Teknika Vol. 1 70-77.

Direktorat Jenderal Cipta Karya, 2018. Pedoman Teknis Pelaksanaan Sanimas IDB 2018. Jakarta : Kementerian Pekerjaan Umum dan Perumahan Rakyat.

Direktorat Jenderal Cipta Karya, Pedoman Umum Program Kota Tanpa Kumuh, 2016 Jakarta: Kementerian Pekerjaan Umum dan Perumahan Rakyat.

Hariyanto, Asep. 2017. Strategi Penanganan Kawasan Kumuh. Jurnal PWK Unisba 11-37.

Jamaluddin, Adon Nasrullah. 2015. Sosiologi Perkotaan Memahami Masyarakat Kota dan Problematikanya. Bandung : Pustaka Setia.

Lubis, D., S. 2016. Strategi Pembangunan Perumahan dan Permukiman Untuk Mengatasi Masalah Permukiman Kumuh di Kota Medan. Jurnal Administrasi Negara Universitas Sumatera Utara 17-30.

Permen PUPR RI No. 14 Tahun 2018 Tentang Pencegahan dan Peningkatan Kualitas Perumahan dan Permukiman Kumuh.

Sembiring, M. A. 2017. Karakteristik Permukiman Kumuh di Kecamatan Medan Denai. Skripsi. Jurusan Pendidikan Geografi Fakultas Ilmu Sosial Universitas Negeri Medan.

Surat Keputusan Walikota Medan No.640/580.K/XI/2018 Tentang Penetapan Lokasi Lingkungan Perumahan dan Permukiman Kumuh di Kota Medan.

UU Nomor 1 Tahun 2011 Tentang Perumahan dan Kawasan Permukiman. 
